\title{
BATHYMETRIC DISTRIBUTION OF BENTHIC MACROINVERTEBRATES IN DEEP LAKE MOTOSU, FUJI FIVE LAKES, JAPAN
}

\author{
KIMIO HIRABAYASHI ${ }^{1, *}$, MASAAKI TAKEDA ${ }^{1}$, NORIHIKO YOSHIDA ${ }^{2}$, \\ KAZUYA YOSHIZAWA ${ }^{3}$, and FUTABA KAZAMA ${ }^{4}$
}

\author{
${ }^{1}$ Department of Applied Biology, Shinshu University, 3-15-1, Tokida, Ueda, Nagano Prefecture, 386-8567 Japan \\ 2 Yamanashi Prefecture University, 5-11-1, Iida, Kofu, Yamanashi Prefecture, 400-0035 Japan \\ ${ }^{3}$ Yamanashi Institute for Public Health, 1-7-31, Fujimi, Kofu, Yamanashi Prefecture, 400-0027 Japan \\ ${ }^{4}$ University of Yamanashi, 4-3-11, Takeda, Kofu, Yamanashi Prefecture, 400-8511 Japan \\ *Corresponding author: kimio@shinshu-u.ac.jp
}

\section{ABSTRACT}

\begin{abstract}
The distribution of benthic macroinvertebrates was studied in deep Lake Motosu (oligotrophic lake), Japan. Bathymetrical sampling surveys were carried out using a standard Ekman grab at each of 16 stations in the lake on 8 March 2013. The average densities of the benthic community for all the stations were 2185 ind./ $\mathrm{m}^{2}$, comprised principally of Tubifex tubifex (Müller) $23.4 \%$, Asellus hilgendorfi Bovallius $4.9 \%$ and chironomids $65.8 \%$. T. tubifex and chironomids inhabited the entire lake bottom, with higher densities in the shallower region $(25 \mathrm{~m}>$ ) than in the deeper region (ca. $120 \mathrm{~m}$ ). On the other hand, the density of A. hilgendorfi increased with water depth and was highest in the deeper regions $(>70 \mathrm{~m}$ ). The densities of chironomid larvae were lower in the deeper region, with fewer chironomid larvae located in the center of the lake (637 ind. $/ \mathrm{m}^{2}$ ). The most abundant species, Micropsectra yunoprima Sasa, exhibited the widest distribution from $10.0 \mathrm{~m}$ to $121.0 \mathrm{~m}$ (mean density 926 ind./ $\mathrm{m}^{2}$ ), followed by Procladius choreusi (Meigen) from $10 \mathrm{~m}$ to $74.1 \mathrm{~m}$ (mean density 365 ind./ $\mathrm{m}^{2}$ ). The results of this study were compared to previous data by Kitagawa (1973) on chironomid larvae. The densities of these chironomid larvae increased throughout the whole lake in 2013. The water quality has not undergone a major change since the 1970's. In this study, the number of M. yunoprima larvae has shown a tendency to increase, especially in shallower regions; where they are widely distributed, suggesting the continuation of favorable bottom condition for larvae since the 1970's.
\end{abstract}

Keywords: chironomid larvae, deep lake, distribution pattern, Micropsectra yunoprima, oligotrophic lake

\section{Introduction}

Numerous studies have been conducted regarding the distribution and abundance of benthic macroinvertebrate populations in relation to various environmental factors (reviewed by Brinkhurst 1974; Real et al. 2000). The hypolimnion oxygen concentration, food quality and quantity, and water temperature are the main factors influencing the presence and biomass of benthic communities, i.e. chironomid larvae and oligochaetes, in lakes and reservoirs (reviewed by Oliver 1971; Jonasson 1996). Thus, benthic macroinvertebrates have been used as indicators of bottom environmental conditions in lakes and reservoirs (Berg et al. 1962; Real et al. 2000). According to Lindegaard (1995), chironomid larvae can provide much information about lake classification and water quality assessment. Recently, Ruse (2010) reported the classification of nutrient impact on lakes using the chironomid fauna. Until now, however, there is sufficient dissolved oxygen in the lake bottom during the summer stagnation period. Moreover, there have been a few studies on the relatively hardly-known chironomid fauna in oligotrophic lakes with their small amount of food/sedimentary organic matter (Sæther 1980). Deep lakes with a large hypolimnion maintain oligotrophic conditions (e.g., shortage of organic matter and high oxygen concentration) in the profundal zone (Lindegaard 1995). The chironomids character- istic of oligotrophic lakes are often free-living (Davies 1975; Grimas and Wiederholm 1979) and thus able to increase their range of foraging to seek scarce food at this end of the trophic spectrum (Wiederholm 1984). Recently, according to Fuentes et al. (2013), their study evaluated the nutritional importance of allochthonous matter supply for profundal macrozoobenthic communities in the deep oligotrophic lake.

Lake Motosu is the third largest of the Fuji Five Lakes in terms of surface area, and is the ninth deepest in Japan. As with the other Fuji Five Lakes, the area is a popular resort, with many lakeside hotels, windsurfing facilities, camp sites, and excursion boats (Tanaka 1992). Rainbow trout and brown trout were introduced into the lake in the Meiji Era, and sports' fishing is also popular (Takahashi 1999). However, in recent years, reduced water transparency due to pollution from these activities has been a growing issue (Tanaka et al. 1982; Yamanashi Prefecture 1993).

In order to clarify the current status of the benthic community of Lake Motosu and examine the difference with the last set of quantitative data by Kitagawa (1973), the bathymetric distribution of benthic macroinvertebrates was studied in this lake, and a comparison of the benthic fauna and density was made between the present and Kitagawa's study. It also discusses the succession of chironomids in relation to ongoing changes in the lake bottom condition. 


\section{Study Site}

Lake Motosu $\left(35^{\circ} 28^{\prime} \mathrm{N}, 138^{\circ} 35^{\prime} \mathrm{E}\right.$ at the center of the lake) has a surface area of $4.83 \mathrm{~km}^{2}$, maximum and mean depths of 122.1 and $67.9 \mathrm{~m}$, respectively, and lies at an altitude of $900.5 \mathrm{~m}$ above sea level at the northern foot of Mount Fuji (Fig. 1). It has no inflowing or outflowing streams. The basin is steep, with its shallow bottom consisting mainly of shattered rocks, lava and sand. Aizaki et al. (1981) classified Lake Motosu as an oligotrophic lake, based on its chlorophyll-a and total phosphorus concentrations, and its water transparency, using the modified Carlson trophic state index (TSI). Recently, Hasegawa and Yoshizawa (2011) measured the total phosphorus, total nitrogen, chlorophyll-a concentration and suspended solids in the surface water every month from 2002 to 2010 . As a result, the water quality has not shown a major change in the 2000's and Lake Motosu was a P-limit lake.
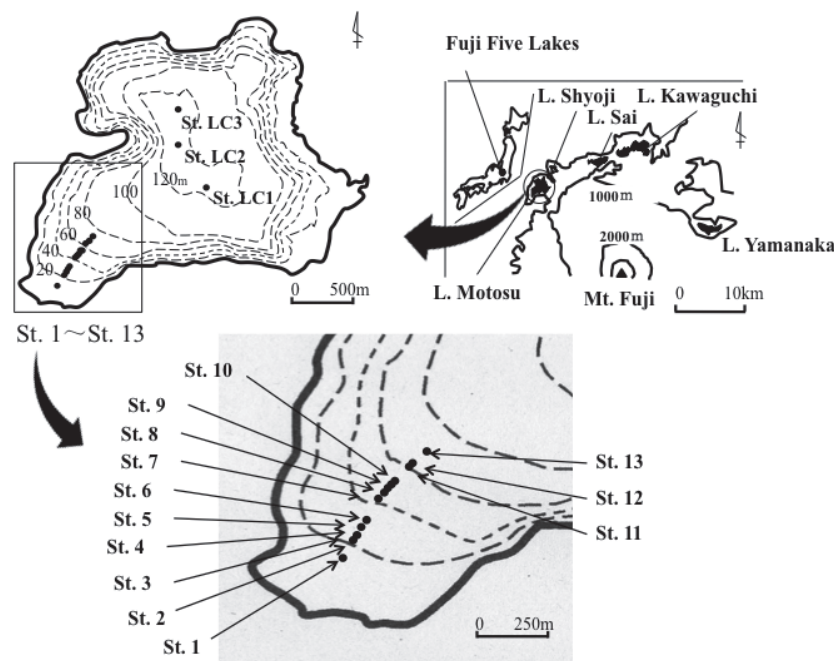

Fig. 1 Maps showing the location of Lake Motosu, isopleths of depth (m) and sampling stations.

\section{Material and Methods}

According to Yamagishi and Fukuhara (1972) and Iwakuma and Yasuno (1981), some species of chironomid larvae, e.g., Propsilocerus akamusi (Tokunaga), burrow deep into the lake bottom sediments to aestivate during the summer. Thus, sampling for chironomid larvae is most efficient from late-autumn to early-spring, when almost all the larvae stay close to the surface of the sediment. A multipoint sampling survey was carried out on 8 March 2013, using a standard Ekman grab $(15 \times$ $15 \mathrm{~cm}$ ). One sample was taken at each of 16 sampling stations (Stations 1 to 13, Lake center; Stations LC1, LC2 and LC3) in Lake Motosu (10-121 m depth; Fig. 1). The sampling points were determined with a Global Positioning System (GPS). After sieving the sediment through a Surber net (GG66; $0.25 \mathrm{~mm}$ mesh size), benthic macroinvertebrates (chironomid larvae, oligochaetes and
Asellus hilgendorfi Bovallius) were counted in the laboratory. Their wet weight was measured with an electronic balance (AND, HM-202).

To identify the chironomids, some larvae were soaked in a $10 \% \mathrm{KOH}$ solution, mounted on slides with gum chloral solution, and examined under a microscope. The chironomids were identified to generic level, utilizing the keys of Cranston (1982), Wiederholm (1983) and Andersen et al. (2013).

To identify chironomid larvae to the species level, other samples were collected at sampling site 13 (74.1 $\mathrm{m}$ depth). The larvae were reared in the laboratory to allow the emergence of adult midges. Moreover, from St. 7 (42.7 m), St. 8 (43.1 m), St. $10(50.1 \mathrm{~m})$ and St. LC1 $(120.5 \mathrm{~m})$, chironomid pupae were collected and some of them were reared and emerged to become adult midges. Adult midges were also collected using sweep nets around the lake. These adult midges were identified to species level, utilizing the key of Wiederholm (1989), Langton and Pinder (2007), and Sasa and Kikuchi (1995). The most abundant species was Micropsectra yunoprima Sasa.

Bottom sediment samples for organic matter content analysis were collected with a core sampler (three $\mathrm{cm}$ inner diameter) at 7 stations, i.e., St. 5, St. 6, St. 12, St. 13, St. LC1, St. LC2 and St. LC3. The mud in the upper three $\mathrm{cm}$ layer of each core was oven-dried at $110^{\circ} \mathrm{C}$ for 2 days and ignited in a muffle furnace at $550^{\circ} \mathrm{C}$ for three hours to determine the ignition loss (IL). At the same station, the core sampler was also used to measure dissolved oxygen concentrations (DO) in the water at the mud-water interface. The water near the mud surface in the core sampler (which remained above the sediment in the core sampler when it was pulled from the water) was siphoned carefully into a glass bottle. The dissolved oxygen concentration was measured using the Winkler method with azide modification. The water temperature (WT) and mud temperature (MT) in the bottom sediments collected in the core sampler were also measured, using a thermistor thermometer (ca. $3 \mathrm{~cm}$ from the sediment surface).

\section{Results}

Table 1 shows the mean values with standard deviations of some environmental factors. WT, MT and DO values were almost the same among the stations on March, 2013 , because the investigation day was during the period of spring overturn. The ignition loss values of the sediment ranged from $9.7 \%$ to $16.1 \%$, with a mean value of $11.4 \pm 2.3 \%$. Most of the lake basin consisted of a soft bottom with an organic matter content higher than $12 \%$. Sediments at St. 5 contained the highest levels of organic matter (16.1\%). Near the center of the lake, i.e., Station LC1 and LC2, the sediment was generally composed of porous volcanic deposits with low IL values $(9.7 \%$ at St. LC1, 9.8\% at St. LC2; Fig. 2). 
Table 1 Mean values and SDs of the environmental factors in March 2013.

\begin{tabular}{|l|l|}
\hline & March 8, 2013 \\
\hline Sampling points & 16 \\
\hline Mean depth $(\mathrm{m})$ & $58.6 \pm 33.8(10.0 \sim 121.0)$ \\
\hline WT $\left({ }^{\circ} \mathrm{C}\right)$ & $7.1 \pm 0.1(7.0 \sim 7.2)$ \\
\hline MT $\left({ }^{\circ} \mathrm{C}\right)$ & $7.4 \pm 1.0(6.4 \sim 8.4)$ \\
\hline DO $(\mathrm{mg} / \mathrm{l})$ & $9.6 \pm 0.7(8.7 \sim 10.4)$ \\
\hline IL $(\%)$ & $11.4 \pm 2.3(9.7 \sim 16.1)$ \\
\hline
\end{tabular}

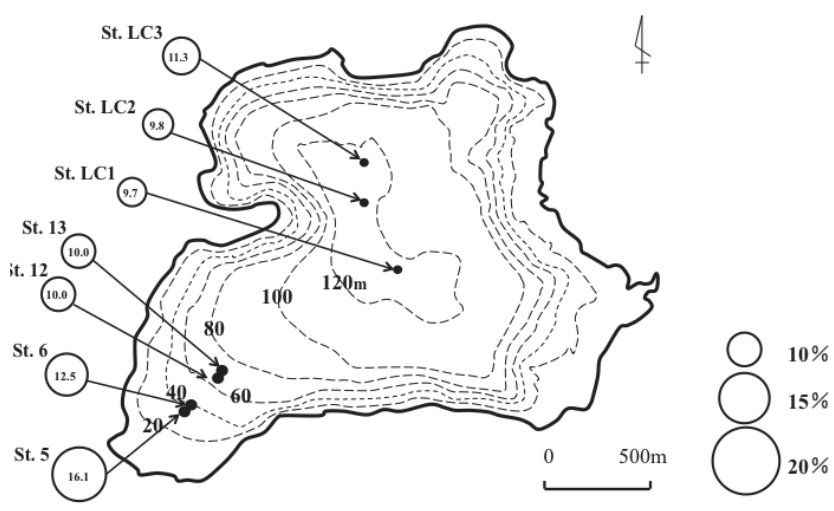

Fig. 2 Horizontal distribution of the ignition loss of sediment in Lake Motosu, in March 2013.

Table 2 shows the mean values with standard deviations of the densities and wet weight of benthic macroinvertebrates, i.e., oligochaetes (Tubifex tubifex (Müller)), Asellus hilgendorfi Bovallius and chironomid larvae. The average densities of the benthic community for all stations were 2,185 ind. $/ \mathrm{m}^{2}$, comprised principally of chironomids 1,437 ind. $/ \mathrm{m}^{2}(65.8 \%)$, T. tubifex $511 \mathrm{ind} . / \mathrm{m}^{2}$ (23.4\%), and A. hilgendorfi 106 ind./m² (4.9\%) (Table 2). On the other hand, the average biomasses (wet weight) of these benthic macroinvertebrates were $2.40 \mathrm{~g} / \mathrm{m}^{2}$ (80.0\%) chironomid larvae, $0.49 \mathrm{~g} / \mathrm{m}^{2}(16.3 \%)$ T. tubifex, and $0.11 \mathrm{~g} / \mathrm{m}^{2}(3.7 \%)$ A. hilgendorfi. Chironomidae species belonging to two subfamilies were found, i.e., two species belonged to the Chironominae and one to the Tanypodinae (Table 2). In density, the most abundant species was Micropsectra yunoprima (Sasa), followed by Procladius choreusi (Meigen) and Stictochironomus akizukii (Tokunaga).

Figures 3 and 4 show the bathymetric distribution of the densities of the main benthos (total chironomid larvae, T. tubifex and A. hilgendorfi; Fig. 3) and the three major species of chironomid larvae (M. yunoprima, P. choreus and S. akizukii; Fig. 4). T. tubifex and total chironomid larvae were widely distributed, but with a peak value at $26 \mathrm{~m}$ depth in shallower regions. Fewer chironomid larvae were found in the center of the lake. The density of these animals decreased with increasing water depth, whereas that of $A$. hilgendorfi increased with water depth; its highest density was in the deeper regions
Table 2 Mean values and SDs of the densities and biomass of benthic macroinvertebrates in March 2013.

\begin{tabular}{|c|c|c|}
\hline No. of samples & 18 (16 st & tions) \\
\hline \multirow[t]{2}{*}{ Mean depth $(\mathrm{m})$} & \multicolumn{2}{|c|}{$58.6 \pm 33.8$} \\
\hline & $\begin{array}{l}\text { Density } \pm \text { SD } \\
\left(\text { Ind. } / \mathrm{m}^{2}\right)\end{array}$ & $\begin{array}{c}\text { Wet-weight } \pm \text { SD } \\
\left(\mathbf{g} / \mathbf{m}^{2}\right)\end{array}$ \\
\hline Total chironomid larvae & $1437 \pm 1132(65.8 \%)$ & $\begin{array}{c}2.40 \pm 1.89 \\
(80.0 \%)\end{array}$ \\
\hline $\begin{array}{l}\text { Chironominae } \\
\text { Micropsectra yunoprima } \\
\text { Stictochironomus akizukii }\end{array}$ & $\begin{array}{l}926 \pm 633 \\
133 \pm 260\end{array}$ & $\begin{array}{l}2.04 \pm 1.40 \\
0.27 \pm 0.52\end{array}$ \\
\hline $\begin{array}{l}\text { Tanypodinae } \\
\text { Procladius choreusi }\end{array}$ & $365 \pm 450$ & $0.09 \pm 0.11$ \\
\hline $\begin{array}{l}\text { Others chironomids } \\
\text { (small size) }\end{array}$ & $13 \pm 24$ & - \\
\hline Tubifex tubifex & $511 \pm 339(23.4 \%)$ & $\begin{array}{c}0.49 \pm 0.32 \\
(16.3 \%)\end{array}$ \\
\hline Asellus (s str.) hilgendorfi & $106 \pm 187(4.9 \%)$ & $0.11 \pm 0.19(3.7 \%)$ \\
\hline Others & $131 \pm 58(5.9 \%)$ & - \\
\hline Total & $\begin{array}{c}2185 \pm 1840 \\
(100 \%)\end{array}$ & $\begin{array}{c}3.00 \pm 1.89 \\
(100 \%)\end{array}$ \\
\hline
\end{tabular}

$(>70 \mathrm{~m})$ and its lowest in the shallower regions $(<40 \mathrm{~m})$. M. yunoprima was widely distributed and the most abundant species at the lake bottom where the depth was from 10 to $121 \mathrm{~m}$ (inhabited all stations), with a peak value at a depth of $10 \mathrm{~m}$. At the lake center, only this species could be collected (mean value, 637 individual number $/ \mathrm{m}^{2}$ ). S. akizukii was mainly collected at only shallower regions $(<25 \mathrm{~m})$ and its density decreased with water depth it was not collected at any sampling station deeper than $45 \mathrm{~m}$. $P$. choreus was widely distributed and abundant at the lake bottom where the depth was from 10 to $74.1 \mathrm{~m}$, with a peak value at a depth of $30 \mathrm{~m}$ - it was not collected at the lake center.

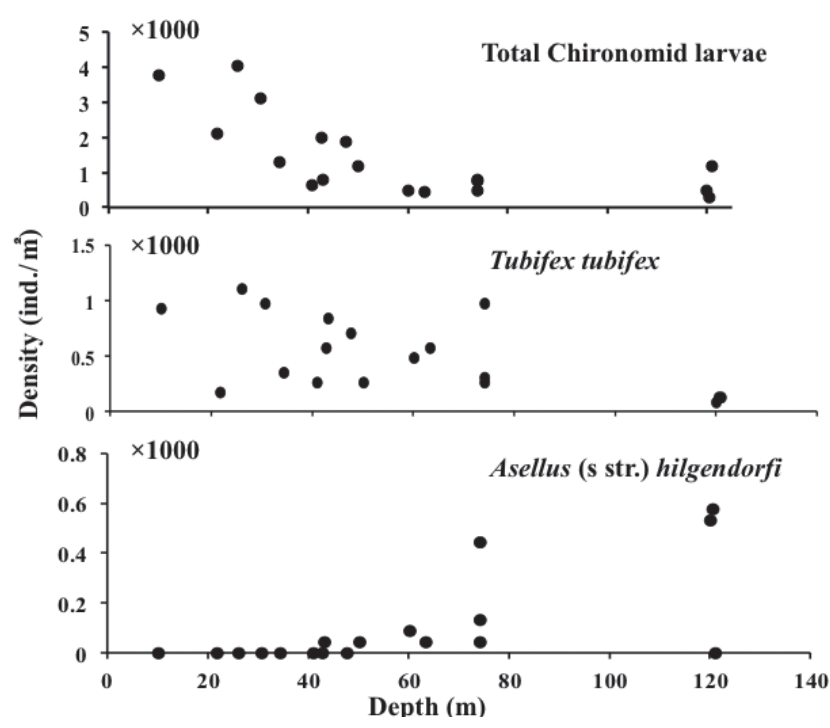

Fig. 3 Bathymetric distribution of the densities of the main benthos in Lake Motosu in March 2013. 


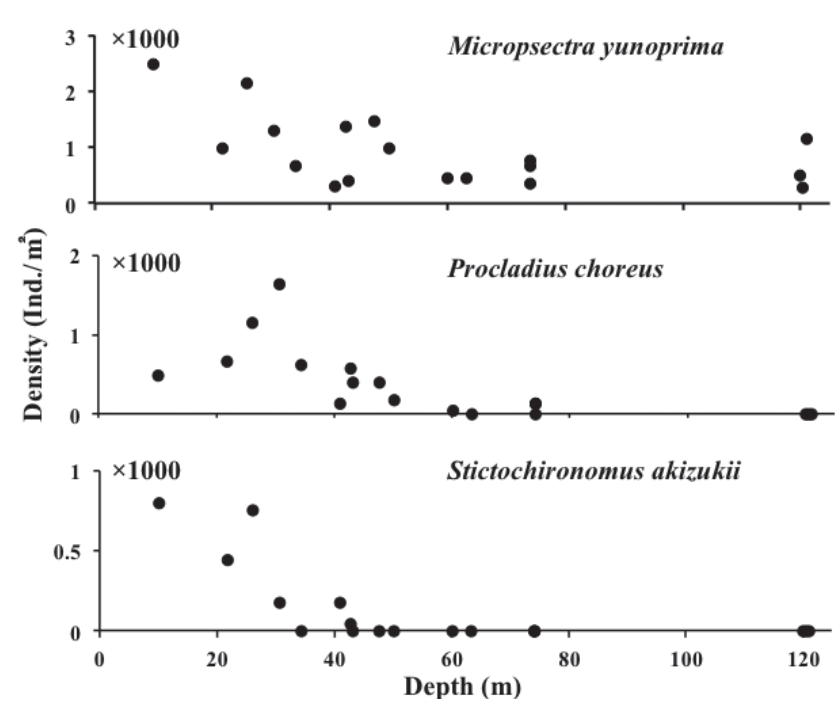

Fig. 4 Bathymetric distribution of the densities of the three major species of chironomid larvae in Lake Motosu in March 2013.

\section{Discussion}

The benthic macroinvertebrates of Lake Motosu have been studied by various researchers (Miyadi 1932; Kitagawa 1973; Yasuno et al. 1983). We compared our results with the previous quantitative data on chironomids and oligochaetes reported by Kitagawa (1973) and tried to clarify the current status of the benthic community (i.e., fauna, density, and distribution pattern) of Lake Motosu. Kitagawa (1973) only reported Micropsectra sp. and Tubifex sp. from this lake on the 11 March 1973 (collecting 18 samples from 16 stations using a standard Ekman grab; there was no mention of the Surber net mesh size and larval rearing method). Micropsectra sp. was widely distributed (from $45 \mathrm{~m}$ to $119.5 \mathrm{~m}$ ) and the most abundant species. However, in this study we recorded three chironomid species, T. tubifex and A. hilgendorfi. Many researchers have used benthic macroinvertebrates as indicators of the trophic state and organic pollution of lakes (Miyadi 1933; Kitagawa 1978; Sæther 1979; Iwakuma et al. 1988; Kawai et al. 1989). According to Brinkhurst (1974), the densities and biomass of benthic macroinvertebrates increased with the progress of lake eutrophication. Table 3 shows the comparison of dominant taxa density of Kitagawa's study with the present investigation. Both studies sampling stations were selected, because their depths were similar in both Kitagawa's study (1973) and in ours. In Lake Motosu, from 1973 to 2013, it is clear that the density of M. yunoprima and T. tubifex showed an increase over that in Kitagawa's report (ca. 3.6 and 2.1 times) (Table 3). M. yunoprima in particular dominated in recent years. Fig. 5 shows the change in distribution pattern of dominant chironomid species in Lake Motosu according to Miyadi (1932) and Kitagawa (1973). Miyadi (1932) reported that a species of the "Tanytarsus genuinus complex" was the dominant taxon on the 8 October 1930 (different season, and thus reference data). The "Tanytarsus genuinus complex" includes many species of the genus Micropsectra Kieffer and it is likely that Tanytarsus genuinus sensu Miyadi (1932) is the same as M. yunoprima. According to Yamanashi Prefecture records (1993), Ariizum et al. (1997) and Yazaki (2011), the water quality (total phosphorus, total nitrogen, COD, DOC, etc.) has not undergone a major change since the 1970's. But, Miyadi (1932) reported that the dissolved oxygen concentration on July 1929 near the bottom (113 m depth) was relatively high $(9.93 \mathrm{mg} / \mathrm{l}$, 88.4\%). Kitagawa (1973) reported that in March 1973 (120m depth) it was also relatively high (ca. $8 \mathrm{mg} / \mathrm{l}$, 73.5\%). Moreover, Hamada et al. (2012) reported that the dissolved oxygen saturation near the lake bottom (121 m depth) at the end of September 2010 was $36.0 \%$. In this study, the number of $M$. yunoprima larvae has shown a tendency to increase, especially in shallower regions; where they are widely distributed, suggesting the continuation of favorable bottom condition for larvae in the shallower regions since the 1970's. But, in the deeper regions (depth $<70 \mathrm{~m}$ ), the DO decreased in the bottom in the period from the 1970s to the 2010s, and the density of M. yunopri$m a$ will decreased if the DO decrease at the bottom in the future.

In this study, M. yunoprima was the dominant species in Lake Motosu, an oligotrophic lake. This species was described from other lakes in the district in a high latitude area (e.g. Lake Toya-ko in Hokkaido; $42^{\circ} 36^{\prime} \mathrm{N}, 140^{\circ} 517^{\prime} \mathrm{E}$, Sasa 1988) and a high mountain area (Lake Taishyo-ike, $1490 \mathrm{~m}$ and Lake Myojin-ike, $1550 \mathrm{~m}$ in Kamikochi; Sasa

Table 3 Changes in dominant chironomid larvae and Tubifex tubifex in Lake Motosu.

\begin{tabular}{|c|c|c|c|c|}
\hline \multirow[b]{2}{*}{ Sampling sites } & \multicolumn{2}{|c|}{$\begin{array}{c}\text { Kitagawa (1973) } \\
\text { March 11, } 1973\end{array}$} & \multicolumn{2}{|c|}{$\begin{array}{l}\text { Present study } \\
\text { March 8, } 2013\end{array}$} \\
\hline & Total 16 & Select 7 & Total 16 & Select $7^{*}$ \\
\hline Mean depth $(\mathrm{m})$ & $97.4 \pm 25.0$ & $88.3 \pm 31.5$ & $58.6 \pm 33.8$ & $88.0 \pm 32.1$ \\
\hline Micropsectra yunoprima (No./m²) & $133 \pm 159$ & $147.9 \pm 150.9$ & $926 \pm 633$ & $539.7 \pm 298.6$ \\
\hline Tubifex tubifex (No./m²) & $705 \pm 1182$ & $160.7 \pm 201.0$ & $511 \pm 339$ & $336.5 \pm 278.6$ \\
\hline Total No. $($ No./m²) & $838 \pm 1117$ & & $2185 \pm 1840$ & \\
\hline
\end{tabular}

* Selected the sampling site, their depth were similar to Katagawa's study (1973) and present study. Recently, the density of M. yunoprima increased about 3.6 times from 1973 to 2014. 
and Hirabayashi 1991; 1993) in Japan. All these lakes are oligotrophic, and the water temperature does not reach more than 20 degrees Centigrade throughout the year (Tanaka 1992). Moreover, according to Sasa and Okazawa (1992), M. yunoprima was collected from low water temperatures in small mountain streams, temporarily shallow puddles, and trout breeding ponds. Consequently, we suggest that this species could be an indicator of low water temperature and oligotrophic conditions.

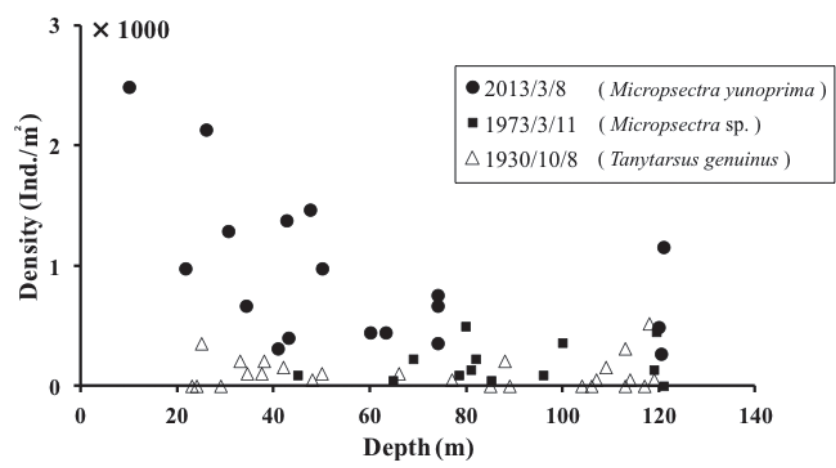

Fig. 5 Changes in distribution pattern of dominant chironomid species in Lake Motosu. Miyadi (1931) reported that a species of the "Tanytarsus genuinus complex", which may be the same as M. yunoprima, was the dominant taxon on the 8 October 1930 (different season, and thus reference data). Kitagawa (1973) reported that Micropsectra sp. was the dominant species on the 11 March 1973.

According to Fu et al. (2013), Micropsectra chuzeprima Sasa, which is closely related taxonomically to M. yunoprima, was the dominant species and widely distributed from 10.1 to $65.5 \mathrm{~m}$ in depth in Lake Saiko, a deep oligotrophic lake (Max. depth $73.2 \mathrm{~m}$ ). Sasa (1984) also described this species from Lake Chuzenji, an oligotrophic lake (Max. depth 163 m). However, M. chuzeprima has fewer collection records than M. yunoprima, and $M$. chuzeprima was collected in environmental conditions approximately similar to M. yunoprima. We assume that the larvae of $M$. chuzeprima are also an indicator of low water temperature and oligotrophic conditions. However, we were not aware of the ecological differences between M. yunoprima and M. chuzeprima in any detail until now and in the future we must clarify this further.

According to Sasa and Kikuchi (1995), the genus Micropsectra in Japan includes about 30 species collected from mesotrophic to oligotrophic lakes. Thus, the presence of the genus Micropsectra cannot be used as an indicator of oligotrophic conditions but individual species might be used as indicators of such conditions. We must investigate and collect much more detailed ecological information about this genus and its Japanese species.

\section{Acknowledgements}

The authors thank Dr Masaru Yamamoto for his valuable taxonomical advice. This study was partly supported by a grant-in-aid for scientific research (No. 24241078) from the Japan Society for the Promotion of Science.

\section{REFERENCES}

Aizaki M, Otsuki A, Fukushima T, Kawai T, Hosomi M, Muraoka K (1981) Application of modified Carlson's trophic state index to Japanese lakes and its relationships to other parameters related to trophic state. Reseach Report from the National Institute for Environmental Studies 23: 13-31.

Andersen T, Cranston PS, Epler J (2013) The larvae of Chironomidae (Diptera) of the Holarctic Region - Keys and diagnoses. Insect Syst Evol Suppl 66: 1-573.

Ariizumi K, Kobayashi H, Watanabe Y, Kobayashi K (1997) Water quality of Fuji Five Lakes at the North of Mt. Fuji in 1996. Annual Report of the Yamanashi Institute for Public Health 41: 63-71.

Berg K, Jonasson PM, Ockelmann KW (1962) The respiration of some animals from the profundal zone of a lake. Hydrobiologia 19: 1-39.

Brinkhurst RO (1974) The benthos of lakes. McMillan Press, London and Basingstoke.

Cranston PS (1982) A key to the larvae of the British Orthocladiinae (Chironomidae). Freshwater Biological Association Scientific Publication 45: 1-152.

Davies IJ (1975) Selective feeding in some arctic Chironomidae. International Vereinigung fur Theoretiscch und Angewandte Limnologie Verhandlungen 19: 3149-3154.

Fu Z, Yoshizawa K, Yoshida N, Kazama F, Hirabayashi K (2012) Bathymetric distribution of chironomid larvae (Diptera: Chironomidae) in Lake Saiko, Japan. Lakes and Reservoirs: Research and Management 17: 55-64.

Fuentes N, Gude H, Straile D (2013) Importance of allochthonous matter for profundal macrozoobenthic communities in a deep oligotrophic lake. Int Rev Hydrobiol 98: 1-13.

Grimas U, Wiederholm T (1979) Biometry and biology of Constempellina brevicosta (Chironomidae) in a subarctic lake. Holarctic Ecol 2: 119-124.

Hamada H, Katsumata D, Oyagi H (2012) Investigation of seasonal change of water temperature and water quality and water balance on Lake Motosu-ko. Annual Report of Faculty of Education, Chiba University 60: 459-468.

Hasegawa Y, Yoshizawa K (2011) Change of the water environment of Fuji Five Lakes. Annual Report of the Yamanashi Institute for Public Health 55: 80-85.

Hayford BL, Caires AM, Chandra S, Girdner SF (2015) Patterns in benthic biodiversity link lake trophic status to strcuture and potentialnfunction of three large, deep lakes. PLOS ONE. doi: 10.1371/journal.pone.0117024.

Iwakuma T, Yasuno M (1981) Chironomid populations in highly eutrophic Lake Kasumigaura. Verhandlungen der Internationalen Vereinigung für Theoretische und Angewandte Limnologie 21: 664-674.

Iwakuma T, Yasuno M, Sugaya Y, Sasa M (1988) Three large species of Chironimdae (Diptera) as biological indicators of lake eutrophication. In: Yasuno M, Whitton AB (eds) Biological monitoring of environmental pollution. Tokai University Press, Tokyo, pp. 101-113.

Jonasson PM (1996) Limits for life in the lake ecosystem. Verhandlungen der Internationalen Vereinigung für Theoretische und Angewandte Limnologie 26: 1-33.

Kawai K, Yamagishi T, Kubo Y, Konishi K (1989) Usefulness of chironomid larvae as indicators of water quality. Jpn J Sanit Zool 40: 269-283.

Kitagawa N (1973) Studies onthe bottom fauna of The Fuji Five Lakes and Lake Ashino (in Japanese). Rikusui Fueiyouka no Kisotekikenkyu 2: 32-37. 
Kitagawa N (1978) A Classification of Japanese Lakes based on Hypolimnetic Oxygen and Benthonic Fauna (in Japanese). Jpn J Limnol 39: 1-8.

Langton PH, Pinder LCV (2007) Keys to the adult male chironomidae of Britain and Ireland. Volume 1 and 2. Freshwater Biological Association 64.

Lindegaard C (1995) Classification of water-bodies and pollution. In: Armitage PD, Cranston PS, Pinder LCV (eds) The Chironomidae: Biology and Ecology of Non-Biting Midges, Chapman and Hall, London, pp. 385-404.

Miyadi D (1932) Studies on the bottom fauna of Japanese lakes. 5. Five Lakes at the north foot of Mt. Hudi and Lake Asi. Jpn J Zool 4: 81-125.

Miyadi D (1933) Studies on the bottom fauna of Japanese lakes. X. Regional characteristics and system of Japanese Lakes based on the bottom fauna. Jpn J Zool 4: 417-437.

Oliver DR (1971) Life history of the Chironomidae. Ann Rev Ent 16: 211-230.

Real M, Rieradevall M, Prat N (2000) Chironomus species (Diptera : Chironomidae) in the profundal benthos of Spanish reservoirs and lakes: factors affecting distribution patterns. Freshwater Biol 43: 1-18.

Ruse L (2010) Classification of nutrient impact on lakes using the chironomid pupal exuvial technique. Ecol Indic 10: 594-601.

Sasa M (1984) Studies on chironomid midges in lakes of the Nikko National Park. Pt. II. Taxonomical and morphological studies on the chironomid species collected from lakes in the Nikko National Park. Research Report National Institute for Environmental Studies No. 70: 16-215.

Sasa M (1988) Studies on the chironomid midges collected from lakes and streams in the southern region of Hokkaido, Japan. Research Report National Institute for Environmental Studies No. 121: 8-76.

Sasa M, Hirabayashi K (1991) Studies on the chironomid midges collected at Kamikochi and Asama-Onsen, Nagano Prefecture. Jpn J Sanit Zool 42: 109-128.

Sasa M, Hirabayashi K (1993) Studies on the additional chironomids collected at Kamikochi and Asama-Onsen, Nagano, Japan. Jpn J Sanit Zool 44: 361-393.
Sasa M, Kikuchi M (1995) Chironomidae (Diptera) of Japan. University of Tokyo Press, Tokyo.

Sasa M, Okazawa T (1992) Studies on the chironomid midges of Kurobe River. Research Report Toyama Prefectural Environmental Pollution Research Center 1992, pp. 40-91.

Sæther OA (1979) Chironomid communities as water quality indicator. Holarctic Ecol 2: 65-74.

Sæther OA (1980) The influence of eutrophication on deep lake benthic invertebrate communities. Prog Wat Technol 12: 161180 .

Takahashi K (1999) Change in fish species in Fuji Five Lakes and Lake Shibire. Report of Yamanashi Prefectural Fisheries Technology Center 26: 57-80.

Tanaka M (1992) The Lakes in Japan. Nagoya University Press, Nagoya.

Tanaka S, Kasai W, Tsutsumi J, Sasamoto J, Nagada T (1982) Results of water quality investigation and water budget of Lake Fuji Five on abnormal increase of water in 1982. Annual Report of the Yamanashi Institute for Public Health 26: 22-28.

Wiederholm T (1983) Chironomidae of the Holarctic region. Keys and Diagnoses. Part 1. Larvae. Entomol Scand Suppl 19: 1-482.

Wiederholm T (1984) Resonse of aquatic insects to environmental pollution. In: Resh VH, Rosenberg DM (eds), Praeger, New York, pp. 508-557.

Wiederholm T (1989) Chironomidae of the Holarctic region. Keys and Diagnoses. Part 3. Adult males. Entomol Scand Suppl 34: $1-532$.

Yamagishi H, Fukuhara H (1972) Vertical migration of Spaniotoma akamusi larvae (Diptera: Chironomidae) through the bottom deposits of Lake Suwa. Jpn J Ecol 22: 226-227.

Yamanashi Prefecture (1993) The water quality of the Fuji Five Lakes over 21 years. Kofu, Yamanashi Prefecture.

Yazaki H (2011) Trends in the concentration of Total organic carbon in Fuji Five Lakes. Annual Report of the Yamanashi Institute for Public Health 55: 77-79.

Yasuno M, Iwakuma T, Sugaya Y, Sasa M (1983) Zoobenthos of Japanese lakes of different trophic status, with special reference to Chironomidae. Research Report of the Special Reserch Project Environmental Science, B182-R12-17: 21-48. 